\section{СПЕЦИФИКА ПЕДАГОГИЧЕСКОГО ПОДХОДА К РОССИЙСКИМ И ИНОСТРАННЫМ СТУДЕНТАМ В ВЫСШЕЙ ШКОЛЕ}

Николаев В.И., Булгакова О.С., Мустафаев Н., Гусейнов Н.

Северо-западный государственный медицинский университет им. И.И. Мечникова, Санкт-Петербург, e-mail:bulgak_os@mail.ru

Эффективность обучения зависит не только от профильных знаний преподавателя, но и от понимания личностных особенностей студентов, с которыми ему приходится работать. Поэтому целью нашего исследования было изучение личностных особенностей российских и иностранных студентов. Были протестированы 6 групп студентов 2-3 курса, три группы иностранцев (60\% молодых людей, $40 \%$ девушек) и три группы российских студентов (30\% молодых людей, 70\% девушек). Всего было обследовано 114 человек (35 иностранцев и 79 россиян). Им были предложены тесты: 1) характерологический опросник Леонгарда; 2) тест «Копинг-стратегии»; 3) Оценка комфортности.

Результаты. Российские юноши - возбудимы и экзальтированны, в группе чувствуют себя не очень комфортно, из всех копинг-стратегий предпочитают самоконтроль, бегство и избегание. Юноши-иностранцы - демонстративны, дистимны и эмоциональны, также со сниженным уровнем комфорта в группе, имеющие пониженное настроение и самочувствие, из всех копинг-стратегий выбирают планирование и социальную поддержку. Российские девушки - в большинстве своем возбудимы, тревожны и неуравновешенны, имеют также сниженный уровень субъективного комфорта, пониженное настроение и самочувствие, из всех копинг-стратегий выбирают дистанцирование и планирование. Девушки-иностранки - демонстративны, гипердистимны или дистимны, непредсказуемы в своих реакция, но имеют высокий уровень субъективного комфорта, хорошее самочувствие, из всех копинг-стратегий предпочитают самоконтроль и бегство-избегание.

Таким образом, выявлены достоверные личностные отличия в четырех группах студентов - российские юноши, юноши-иностранцы, российские девушки, девушки-иностранки. Понимание этой специфики и педагогом и самими студентами может помочь в организации эффективного педагогического процесса.

\section{ОРГАНИЗАЦИЯ ДВИЖЕНИЯ ТРАНСПОРТНЫХ ПОТОКОВ НА СЛОЖНЫХ РАЗВЯЗКАХ В ОДНОМ УРОВНЕ}

Кузнецов В.Н.

ИАиС ВолгГТУ, Волгоград, e-mail: vnk3@yandex.ru

Пересечения и развязки в одном уровне являются местами с наиболее часто возникающими ДТП и задержками движения. В России более $20 \%$ общего числа ДТП происходит на пересечениях в одном уровне. Поэтому организация движения и оптимизация светофорного регулирования в таких местах является первоочередной задачей обеспечения пропускной способности и безопасности движения.

С развитием дорожной сети в России количество различных пересечений автомобильных дорог неизбежно увеличивается, что существенно оказывает влияние на условия движения транспортных потоков.

Постоянные изменения скоростей движения автомобильных потоков, смена полос движения, ведет к уплотнению транспортного потока и снижению пропускной способности в зоне пересечения.

Поэтому необходимо найти оптимальные планировочные решения пересечений в одном уровне. Одним из оптимальных решений является проектирование кольцевых пересечений в одном уровне.

Кольцевые пересечения были созданы для саморегулируемого и без остановочного движения транспорта на пересечениях большого количества дорог [1].

Впервые использование кольцевых пересечений былопредложено в 1877 году французским архитектором Юджином Энардом (Eugene Henard) [1].

При использовании данного вида организации движения повысилась пропускная способность и уровень безопасности движения на кольцевых пересечениях.

На основе обобщения иностранного опыта в 60-е годы, были созданы первые кольцевые пересечения в СССР.

Однако эффективность кольцевых пересечений значительно снижается в случае высокой интенсивности движения. Частичное решение данной проблемы было найдено с применением так называемых «турбо-колец», однако не во всех случаях можно применить данный тип организации движения.

Несмотря на то, что кольцевые пересечения замедляют транспортные потоки, этот тип развязок остается самым быстрым способом проезда в сравнении с другими типами одноуровневых развязок.

Кольцевые пересечения устраиваются при пересечении (в одной точке) трех, четырех 